\title{
AN ANALYSIS OF STUDENTS' MOTIVATION IN STUDYING ENGLISH DURING COVID-19 PANDEMIC
}

\author{
Putu Subakthiasih ${ }^{1}$ \\ Universitas Mahasaraswati Denpasar \\ I Gusti Ayu Vina Widiadnya Putri ${ }^{2}$ \\ Universitas Mahasaraswati Denpasar \\ vina.ayu4221@gmail.com ${ }^{1}$
}

Submit, 30-10-2020 Accepted, 22-12-2020 Publish, 28-12-2020

\begin{abstract}
This study focuses to investigate students' motivation in studying English during Covid-19 Pandemic, whether they had intrinsic or extrinsic motivation. This research was a survey method and the technique sampling used in this study was random sampling. Furthermore, the instrument used questionnaire to collect the data. The questionnaire consists of 20 questions in which question 1-10 are questions for intrinsic motivation. The question 11-20 are extrinsic motivation. The result of this study shows that the total mean score of intrinsic motivation is higher than the total mean score of extrinsic motivation $4.20>3.39$. It means that first semester of English students at Faculty of Foreign Language, Mahasaraswati Denpasar University had the higher intrinsic motivation than extrinsic motivation in learning English during Covid-19 Pandemic. In other words, the motivation to learn English that comes from inside students was higher than the motivation comes from outside students.
\end{abstract}

Keywords: Students' Motivation, Studying English, Covid-19 Pandemic

\section{INTRODUCTION}

The achievement of the goals of education is the principal task of someone who deals directly with policy making and implementer education. According to Akbar \& Hawadi, (2001), the achievement of educational success can be realized by many factors that influenced the internal factor of student or external factor of student. The achievement of learning that achieved by the students is the factor of the interaction between both of those factors.

At this time, the pandemic covid-19 forced the government to issue social distancing rules. This problem has an impact on all aspects including the problem of education, so the government set distance learning during this pandemic covid19. Basically distance education is a type of education where students are far from educators, so education cannot be done face-to-face and the delivery of messages 
from educators to students must be done through the media (Pgri et al., 2020). Physical separation between instructors and students in distance education has implications for the limited interaction between teachers and students. A teacher in distance learning cannot guide and supervise the learning of individual students on an as regular basis as in face-to-face education, so this distance learning becomes a challenge for educators whether their learning interest is maintained. Students' interest in learning during the Covid-19 pandemic must be maintained and there is also need students' motivation when do the learning process in covid19 pandemic. Motivation has an important role in learning. Student's achievement is related to the way of thinking, feeling and behavior of students. Students who have problems at school, they show the level of motivation is low. Teachers need to seek an increase in student's achievement motivation by providing support in the form of awards/ reinforcement for his achievements, paying attention to awareness, giving feedback and making students have felt the ability.

Therefore, motivation in learning can be divided into two categories; intrinsic motivation and extrinsic motivation. Harmer, (2001) stated that intrinsic motivation comes from within individual. Motivation comes from inside an individual rather than from any external or outside rewards, such as money or grades. Students who have intrinsic motivation would have pleasure one gets from the task itself or from the sense of satisfaction in completing or even working on a task.

On the other hand, extrinsic motivation also influences students in learning. Harmer, (2001) stated that "extrinsic motivation is the result of any number of outside factors". These outside factors include reward and punishment. Extrinsic motivation does not mean that student will not get any pleasure from learning on or completing a task. It just means that the pleasure they anticipate from some externals reward will continue to be a motivator even when the task to be done holds little or no interest.

Mahasaraswati University is one of campus in Denpasar, Bali. Many people believe that the Faculty of Foreign Language this department can produce intellectual and skillful alumna especially in mastering and applying English in all sectors. Therefore, almost all candidates of college students who want to learn English choose this campus as the first choice to study. However, among all students of Mahasaraswati University who studied at Faculty of Foreign Language in the first semester, they absolutely had different motivation to choose learning English during covid-19 pandemic. Therefore, this study tries to find out the kind of motivation had by English students in learning English during covid-19 pandemic. Based on explanation above, the research problem of this study is formulated as follow: "what kind of motivation had by first semester English 
students in Faculty of Foreign Language at Mahasaraswati University in learning English during covid-19 pandemic?

The objective of the study is to know the students' motivation in first semester of Foreign Language at Mahasaraswati University while studying English during covid-19 pandemic. There are some researchers who have conducted the study on analysis students' motivation that analyzed different objects. The first previous researcher is Pgri et al., (2020) in their research entitled "Learning Motivation and Students' Achievement in Learning English: A Case Study at Secondary School Students in the Covid-19 Pandemic Situation", their analyzed students' motivation in learning, and students' achievement learning English, in the current situation of covid-19 pandemic. The research showed that the changes of students' learning motivation then have an impact on students' achievement so that teacher have delivered lesson materials to students that are not significantly different from the situation in normal conditions because this makes the students' motivation and achievement in learning does not significantly decrease.

Some previous study that relevant in this study is from Purnama et al., (2019), their analyzed to know how students' motivation in learning English of eight grade at MTs Mathla'ul Anwar Sukaguna. From this research, students of eighth grade at MTs Mathla'ul Anwar have a motivation in studying English, it is from the output of questionnaire, most of students concur with the statements of questionnaire. It means that students have the desire in studying English. Furthermore, the output of interview also described that students have motivation in studying English. In this research showed motivation is the influential factor in learning activity and the other teacher need to be more creative in using the media, strategy, or delivered material in learning activity to improve students' motivation. Supported by Purwanto et al., (2020) their analyzed was to explore the Covid-19 Pandemic's Impact on the Students of Indonesian Universities Performance. The results of this study are that there are impacts of Covid-19 Pandemic on the Students of Indonesian universities performance such as some of the negative effects of Covid-19 are that many students have psychological impact.

Moreover, the presence of Corona virus makes this more likely to have an impact on anxiety disorder symptoms, a lot of income in a family is lost, which makes a reduction in allowance. This research showed students can study at home feel more comfortable and have a new atmosphere and can help parents to work or do other work. The process of studying at home is more relaxing and they can do other work to earn extra income. The learning process at home is more comfortable and they also can save costs especially transportation costs, do not experience traffic jams. 
Huang, (2020), stated that In the midst of covid-19 pandemic, the students are interested in using online learning in which can be accessed flexible, anywhere and everywhere. The best application used by lecturers and students was WhatsApp application. Then, it can be concluded that the students' perspective on online learning had a positive impact in the midst of the covid-19 pandemic. Learning process need for good communication between academic supervisors and students regarding learning motivation in PJJ and the need to create study groups so that students remain active during the Covid-19 period through online groups (Anugrah \& Silitonga, 2020). Supported by Fuentes Hernández et al., (2020), this study is to know the e-learning modality that stimulates students' learning process according to twenty-two English teachers in Santander, Colombia, and the correlation between learners' motivation and the challenges and opportunities in an online EFL class, They mentioned that motivation is one of the factors that has proven to be extremely important in effective learning processes of apprentices of foreign languages.

Lestari, (2020), the research showed the enhancement can be seen from the higher of mean from each class' English score and the timeliness in submitting of the assignment and evaluation in e-learning using JBClass during COVID-19 pandemic. Last is from Krishnapatria, (2020) this research is motivated by the need of exploring the students' perception of e-learning implementation of two English language subjects in the time of COVID-19 pandemic. Then, it showed that fair assessment of students' perception in e-learning may grant a good precedent in the implementation of full online learning due to physical isolation caused by the COVID-19 pandemic, which alternatively can be done with the method of blended learning in the New Normal.

Based on the previous studies above there are differences of this research with them, the writer analyzed the students' motivation in learning English during Covid-19 Pandemic. This research is done to extend the previous research in analysis research by give attention for kind of motivation had by first semester English students in Faculty of Foreign Language at Mahasaraswati University in learning English during covid-19 pandemic.

\section{LITERATUR REVIEW}

\section{Theories of Motivation}

Etymologically, Purnama et al., (2019) explains the term motivation comes from the Latin word, movere (to move) and then absorbed in English language into motivation which means providing motivate or cause of motivate that led of encouragement. Next, he points out motivation of a person depend on the strength of his or her motivate. So, the motivation cannot be separated from 
the concept of motivate In essences it can be said that the motivate is a cause of action.

Motives are hypothetical constructs used to explain why people are doing what they are doing. Motives are distinguished from related constructs such as goals (the immediate objectives of particular sequences of behavior) and strategies (the methods used to achieve goals and thus to satisfy motives). For example, a person responds to hunger (motive) by going to a restaurant (strategy) to get food (goal). Motives are usually construed as relatively general needs or desires that energize people to initiate purposeful action sequences.

In contrast, goals (and related strategies) tend to be more specific and to be used to explain the direction and quality of action sequences in particular situations (Elliot \& Murayama, 2008). Motives, goals, and strategies can be difficult to distinguish in situations that call for intentional learning of cognitive content (such as the content of this book), because optimal forms of motivation to learn and optimal strategies for accomplishing the learning tend to occur together. In the classroom context, the concept of student motivation is used to explain the degree to which students invest attention and effort in various pursuits, which may or may not be the ones desired by their teachers. Student motivation is rooted in students' subjective experiences, especially those connected to their willingness to engage in lessons and learning activities and their reasons for doing so. This book develops the argument that teachers' primary motivational goals and strategies should focus on encouraging students to engage in activities with motivation to learn: That is, with the intention of acquiring the knowledge or skills that the activities are intended to develop.

\section{Kinds of Motivation}

Motivation is the driving force of a person to performance achieve a goal. Motivation can also be said as a plan or desire for success and avoid failure of life. In other words, motivation is a process for achieving a goal. Someone who has motivation means he/she already has the power to gain success in life.

Motivation has been formulated in a number of different definitions. Even so, the substance is not much different.

According to Sepora, \& Sepideh, (2012), motivation is commonly thought of as an inner drive, impulse, emotion, or desire that moves one to a particular action. Motivation was examined as a factor of attitudes divided into two basic types of motivation, such as instrumental and integrative motivation. Instrumental motivation refers to motivation to acquire a language as means for attaining instrumental goals: furthering a career, reading technical material, and translation. An integrative motivation is employed when a learner wishes to integrate himself within the culture of the second language group, to identify himself with and 
become a part of that society. From the conclusion of this study is that integrative motivation may indeed be an important for successful language learning and some claim that integrative motivation is absolutely essential for successful second language learning.

Another types of motivation is also defined by Morris, \& Maisto, (2002). Motivation can be divided into two terms, such as intrinsic motivation and extrinsic motivation. In term of Intrinsic motivation is the ultimate goal in education at every level. Intrinsic motivation refers to rewards provided by an activity itself. The motivation arises from internal factors such as a child's natural feeling of curiosity, exigent, confidence and satisfaction when performing a task. People who are involved in a task because of intrinsic motivation appear to be engaged and even consumed, since they are motivated by the activity itself and not some goal that is achieved at the end or as a result of the activity. Meanwhile, extrinsic motivation refers to rewards that are obtained not from the activity, but as a consequence of the activity. This motivation arises from the use of external rewards or bribes such as food, praise, free time, money or points toward an activity. These incentives are all external, in that they are separate from the individual and the task.

\section{Measurement of Motivation}

There are some ways used to measure motivation according to (Hanafiah, 2010):

1. Performance test is the measurement to get information about loyalty, sincerity, targeting, awareness, duration, and frequency of activist.

2. Questionnaire is to know the persistence and loyalty.

3. Free compose is to understand information about the vision and aspirations.

4. Achievement test is to get the information

5. Scale is to understand information about attitude.

\section{RESEARCH METHOD}

The study was analysis of students' motivation in studying English during Covid-19 Pandemic. The researchers used quantitative method for the present study. The first semester students on Faculty of Foreign Language at Mahasaraswati University were the population. Simple random sampling technique was used for the data collection from the respondent. In process of sample selection, this research done to analyze students' motivation in first semester. Questionnaire technique to collect the data. Questionnaire developed on Likert Scale from 20 items. Questionnaire distributed among graduates and data was collected from 90 students. Collected raw data was analyzed through SPSS and most frequently used statistical techniques of frequency and percentage score 
used. The aforesaid statistical technique is suitable in achieving the objective of the study.

\section{Participants}

In this present study, the first semester students on Faculty of Foreign Language of Mahasaraswati University in the academic years 2020/2021 was selected as the population. Based on the data taken from the department, the researcher got the number of English students were 180. Moreover, the sample taken in this research was 90 of first semester English students. Technique sampling used in this research was random sampling. Table showed the distribution of students in each class.

Table 1. Distribution of Participants

\begin{tabular}{cc}
\hline Class & Number of Students \\
\hline I A & 15 \\
\hline I B & 15 \\
\hline I C & 15 \\
\hline I D & 15 \\
\hline I E & 15 \\
\hline I F & 15 \\
\hline Total & $\mathbf{9 0}$ \\
\hline
\end{tabular}

\section{Instrument}

Instrument used in this study was questionnaire. It consists of ten questions in which the questions number 1-10 are the questions to collect the information about intrinsic motivation and questions number 11-20 are questions for extrinsic motivation. The questionnaire used in this research is close questionnaire.

\section{Questionnaire Tests}

This questionnaire used Likert scale or summative scaling to measure the extent to which the respondent agreed or disagreed with the questions. The response is classified into five categories, such as: strongly agree, agree, doubt, disagree and strongly disagree. The researcher adopted the questionnaire from Gardner's Attitude and Motivation cited in (Jefiza, 2017). The questions for intrinsic and extrinsic motivation are represented as below. 
Table 2. Intrinsic Motivation Questions

\begin{tabular}{|c|c|c|c|c|c|c|}
\hline No. & Intrinsic Motivation & $\begin{array}{c}\text { Strongly } \\
\text { Agree }\end{array}$ & Agree & Neutral & Disagree & $\begin{array}{l}\text { Strongly } \\
\text { Disagree }\end{array}$ \\
\hline 1. & $\begin{array}{l}\text { I Learn English in } \\
\text { order to improve } \\
\text { my English language } \\
\text { skills while the } \\
\text { Covid-19 Pandemic. }\end{array}$ & & & & & \\
\hline 2. & $\begin{array}{l}\text { Knowing English } \\
\text { helps me become a } \\
\text { better person. }\end{array}$ & & & & & \\
\hline 3. & $\begin{array}{l}\text { I used the free time } \\
\text { for learning English } \\
\text { in Covid-19 } \\
\text { Pandemic. }\end{array}$ & & & & & \\
\hline 4. & $\begin{array}{l}\text { I still study English } \\
\text { while Covid-19 } \\
\text { Pandemic because I } \\
\text { enjoy study English } \\
\text { it. }\end{array}$ & & & & & \\
\hline 5. & $\begin{array}{l}\text { English helps/will } \\
\text { help me learn about } \\
\text { other cultures, values } \\
\text { and thoughts. }\end{array}$ & & & & & \\
\hline 6. & $\begin{array}{l}\text { When I speak } \\
\text { English, I don't mind } \\
\text { making mistakes. }\end{array}$ & & & & & \\
\hline 7. & $\begin{array}{l}\text { Learning English is } \\
\text { very important during } \\
\text { Covid-19 Pandemic }\end{array}$ & & & & & \\
\hline 8. & $\begin{array}{l}\text { Learning English will } \\
\text { allow me to be more } \\
\text { at ease with English } \\
\text { speakers. }\end{array}$ & & & & & \\
\hline 9. & $\begin{array}{l}\text { When someone } \\
\text { speaks to me in } \\
\text { English, I tend to be } \\
\text { nervous. }\end{array}$ & & & & & \\
\hline 10 & $\begin{array}{l}\text { If I could not go to } \\
\text { Campus, I would } \\
\text { learn English by } \\
\text { myself. }\end{array}$ & & & & & \\
\hline
\end{tabular}


Table 3. Extrinsic Motivation Questions

\begin{tabular}{|c|c|c|c|c|c|c|}
\hline No. & $\begin{array}{c}\text { Extrinsic } \\
\text { Motivation }\end{array}$ & $\begin{array}{c}\text { Strongly } \\
\text { Agree }\end{array}$ & Agree & Neutral & Disagree & $\begin{array}{l}\text { Strongly } \\
\text { Disagree }\end{array}$ \\
\hline 1. & $\begin{array}{l}\text { Learning English is } \\
\text { useful in } \\
\text { getting a good job in } \\
\text { Covid-19 Pandemic. }\end{array}$ & & & & & \\
\hline 2. & $\begin{array}{l}\text { I learn English } \\
\text { because I need it to } \\
\text { further my studies } \\
\text { overseas. }\end{array}$ & & & & & \\
\hline 3. & $\begin{array}{l}\text { I study English in } \\
\text { order to please my } \\
\text { family. }\end{array}$ & & & & & \\
\hline 4. & $\begin{array}{l}\text { I feel that no one is } \\
\text { really educated } \\
\text { unless he is fluent in } \\
\text { English language. }\end{array}$ & & & & & \\
\hline 5. & $\begin{array}{l}\text { Knowing English } \\
\text { gives me a feeling of } \\
\text { success especially in } \\
\text { Covid-19 Pandemic. }\end{array}$ & & & & & \\
\hline 6. & $\begin{array}{l}\text { Others will have a } \\
\text { better opinion of me } \\
\text { if I speak English. }\end{array}$ & & & & & \\
\hline 7. & $\begin{array}{l}\text { In an English class, } \\
\text { the teacher } \\
\text { personality is } \\
\text { important in Covid- } \\
19 \text { Pandemic. }\end{array}$ & & & & & \\
\hline 8. & $\begin{array}{l}\text { In an English class, } \\
\text { the group is } \\
\text { important. }\end{array}$ & & & & & \\
\hline 9. & $\begin{array}{l}\text { I study English } \\
\text { because I want to do } \\
\text { well in my } \\
\text { Examination. }\end{array}$ & & & & & \\
\hline 10. & $\begin{array}{l}\text { In an English class, } \\
\text { the teacher's method } \\
\text { is important. }\end{array}$ & & & & & \\
\hline
\end{tabular}

The students were asked to answer the question by choosing four categories $\mathrm{SA}=5, \mathrm{~A}=4, \mathrm{~N}=3, \mathrm{D}=2$ and $\mathrm{SD}=1$. The score of questionnaire is based on the table below: 
Table 4. Likert Scale Rating

\begin{tabular}{ccc}
\hline \multirow{2}{*}{ Optional } & \multicolumn{2}{c}{ Score } \\
\cline { 2 - 3 } & Intrinsic Motivation & Extrinsic Motivation \\
\hline Strongly Agree & 5 & 5 \\
\hline Agree & 4 & 4 \\
\hline Neutral & 3 & 3 \\
\hline Disagree & 2 & 2 \\
\hline Strongly Disagree & 2 & 1 \\
\hline
\end{tabular}

Source : (Salamat et al., 2018)

\section{Procedures}

In order to obtain the intended data, several procedures will be conducted. Those steps, such as: all instrument needed during the experiment were prepared in advance by the researcher, the sample were selected randomly by using random sampling, questionnaire used as a research tool for data collection, collected raw data was analyzed through SPSS and most frequently used statistical techniques of frequency and percentage score used.

The data obtained from the questionnaires were analyzed by calculating the mean for each question. A five-point Likert scale was used to measure the level and type of subjects' learning motivation. Such scale was used in the questionnaire to determine the level of agreement or disagreement of students' answer based on the following criteria:

Table 5. Standard of Mean

\begin{tabular}{cc}
\hline Mean Range & Interpretation \\
\hline $3.68-5.00$ & High degree of motivation \\
\hline $2.34-3.67$ & Moderate degree of motivation \\
\hline $1.00-2.33$ & Low degree of motivation \\
\hline
\end{tabular}

Source : (Salamat et al., 2018)

\section{FINDING}

This research find out What kind of motivation had by first semester English students in Faculty of Foreign Language at Mahasaraswati University in learning English during covid-19 pandemic either intrinsic motivation or extrinsic motivation. To get the data, the researcher used questionnaire consisting of 20 questions. Question numbers 1-10 are questions for intrinsic motivation while question numbers 11-20 are questions for extrinsic motivation. 
Based on the result of the questionnaires, the following table presents 5 statements items about intrinsic motivation, their means scores, and their corresponding motivation level which were serve as the basis for further interpretation and explanation.

Table 6. Intrinsic Motivation

\begin{tabular}{|c|c|c|c|}
\hline No. & Intrinsic Motivation & Mean & $\begin{array}{c}\text { Rating of Motivational } \\
\text { Level }\end{array}$ \\
\hline 1. & $\begin{array}{l}\text { I Learn English in order to improve } \\
\text { my English language skills while } \\
\text { the Covid-19 Pandemic. }\end{array}$ & 4.30 & High \\
\hline 2. & $\begin{array}{l}\text { Knowing English helps me become } \\
\text { a better person. }\end{array}$ & 4.48 & High \\
\hline 3. & $\begin{array}{l}\text { I used the free time for learning } \\
\text { English in Covid-19 Pandemic. }\end{array}$ & 4.04 & High \\
\hline 4. & $\begin{array}{l}\text { I still study English while Covid-19 } \\
\text { Pandemic because I enjoy study } \\
\text { English it. }\end{array}$ & 4.08 & High \\
\hline 5. & $\begin{array}{l}\text { English helps/will help me learn } \\
\text { about other cultures, values and } \\
\text { thoughts. }\end{array}$ & 4.42 & High \\
\hline 6. & $\begin{array}{l}\text { When I speak English, I don't mind } \\
\text { making mistakes. }\end{array}$ & 4.64 & High \\
\hline 7. & $\begin{array}{l}\text { Learning English is very important } \\
\text { during Covid-19 Pandemic }\end{array}$ & 4.10 & High \\
\hline & $\begin{array}{l}\text { Learning English will allow me to } \\
\text { be more at ease with English } \\
\text { speakers. }\end{array}$ & 4.32 & High \\
\hline 9. & $\begin{array}{l}\text { When someone speaks to me in } \\
\text { English, I tend to be nervous. }\end{array}$ & 3.59 & Moderate \\
\hline 10. & $\begin{array}{l}\text { If I could not go to Campus, I would } \\
\text { learn English by myself. }\end{array}$ & 4.09 & High \\
\hline & Total & 4.20 & High \\
\hline
\end{tabular}

Table 6. above shows the result of questionnaire related to English students' intrinsic motivation. The data from the table shows that the total mean for intrinsic motivation is high in rating of motivational level. The total score is 4.20. Moreover, each statement for intrinsic motivation question also got high rating level. Statement number 1 (I Learn English in order to improve my English language skills while the Covid-19 Pandemic) and number 2 (Knowing English 
helps me become a better person) had the average mean score 4.30 and 4.48 . From both of these statements, it proves that the students had high motivation in learning English. Their goal in learning English for them is to improve their language skills. Besides, statement number 3 (I used the free time for learning English in Covid-19 Pandemic) and number 4 (I still study English while Covid19 Pandemic because I enjoy study English it) had the mean score 4.04 and 4.08, it showed that students enjoyed to study English while Covid-19 Pandemic. Then, statement number 5 (English helps/will help me learn about other cultures, values and thoughts) and number 6 (When I speak English, I don't mind making mistakes) had the mean score 4.42 and 4.64. Those statements showed the high degree of motivation, it means that English is very helpful for learn about different other cultures, values and thoughts. Furthermore, the statement number 7 (Learning English is very important during Covid-19 Pandemic), statement number 8 (Learning English will allow me to be more at ease with English speakers) and statement number 10 (If I could not go to Campus, I would learn English by myself) had the mean score 4.10, 4.32 and 4.09 showed high degree of motivation so that English is very important for students. However, the statement number 9 (When someone speaks to me in English, I tend to be nervous) got 3.59. It is the lowest score among the others. The table below showed that students' extrinsic motivation in learning English during Covid-19 Pandemic.

Table 7. Extrinsic Motivation

\begin{tabular}{lllc}
\hline No. & \multicolumn{1}{c}{ Extrinsic Motivation } & Mean & $\begin{array}{c}\text { Rating of Motivational } \\
\text { Level }\end{array}$ \\
\hline $\begin{array}{l}\text { 1. } \\
\text { Learning English is useful in } \\
\text { getting a good job in Covid-19 } \\
\text { Pandemic. }\end{array}$ & 3.92 & High \\
\hline 2. & $\begin{array}{l}\text { I learn English because I need it to } \\
\text { further my studies overseas. }\end{array}$ & 4.07 & High \\
\hline 3. & $\begin{array}{l}\text { I study English in order to please } \\
\text { my family. }\end{array}$ & 3.27 & Moderate \\
\hline 4. & $\begin{array}{l}\text { I feel that no one is really educated } \\
\text { unless he is fluent in English } \\
\text { language. }\end{array}$ & 2.88 & Moderate \\
\hline 5. & $\begin{array}{l}\text { Knowing English gives me a feeling } \\
\text { of success especially in Covid-19 } \\
\text { Pandemic. }\end{array}$ & 3.64 & Moderate \\
\hline 6. & $\begin{array}{l}\text { Others will have a better opinion of } \\
\text { me if I speak English. }\end{array}$ & 3.61 & \\
\hline
\end{tabular}




\begin{tabular}{llcc}
\hline 7. & $\begin{array}{l}\text { In an English class, the teacher } \\
\text { personality is important in Covid-19 }\end{array}$ & 4.07 & High \\
& & \\
\hline $\begin{array}{l}\text { Pandemic. } \\
\text { 8. }\end{array}$ & $\begin{array}{l}\text { In an English class, the group is } \\
\text { important. }\end{array}$ & 4.29 & High \\
\hline 9. & $\begin{array}{l}\text { I study English because I want to do } \\
\text { well in my examination. }\end{array}$ & 4.19 & High \\
\hline $\begin{array}{l}\text { In an English class, the teacher's } \\
\text { method is important. }\end{array}$ & 4,68 & High \\
\hline & \multicolumn{1}{c}{ Total } & 3.39 & Moderate \\
\hline
\end{tabular}

The table 7. above, it can be seen that the total mean score for extrinsic score is 3.39. It means that students' extrinsic motivation is in moderate level. From statement number 1 (Learning English is useful in getting a good job in Covid-19 Pandemic) and number 2 (I learn English because I need it to further my studies overseas) had the average mean score 3.92 and 4.07 showed learning English is useful in the Covid-19 Pandemic. Then, number 7 (In an English class, the teacher personality is important in Covid-19 Pandemic) and number 8 (In an English class, the group is important) got mean score 4.07 and 4.29, it showed that teaching and learning process is very important when student want to learn English in the Covid-19 pandemic. Furthermore, number 9 (I study English because I want to do well in my examination) and number 10 (In an English class, the teacher's method is important) had the average score was 4.19 and 4.68 with the same high degree of motivation showed teachers' method support the success in learning process. Moreover, the statement number 3 (I study English in order to please my family), number 4 (I feel that no one is really educated unless he is fluent in English language) got 3.27 and 2.88 or in moderate level. For statement, number 5 (Knowing English gives me a feeling of success especially in Covid-19 Pandemic) and number 6 (Others will have a better opinion of me if I speak English), the scores of students' extrinsic were 3.64 and 3.61 or in moderate level.

\section{DISCUSSION}

Learning English in Pandemic Covid-19 is the teacher and student challenging. Students can be more consistent in choosing answers in the questions given when getting the assessment (Putri, 2019). Intrinsic motivation is a type of motivation that was derived from inside of the students. The first semester English students of Faculty of Foreign Language in Mahasaraswati University enjoy learning English because their own desire and their own pleasure. There are some reasons why the students have intrinsic motivation in 
learning English during the Covid-19 Pandemic such as students learn English in order to improve their English language skills while the Covid-19 Pandemic, knowing English helps students become a better person, students used their free time for learning English in Covid-19 Pandemic, students still study English while Covid-19 Pandemic because they enjoy study English, students believe that English helps/will help me learn about other cultures, values and thoughts, students also have self-confidence because when students speak English, they do not mind making mistakes, learning English by their self during the COVID-19 Pandemic. From those reason the students will drive to make an effort to achieve their reasons and their goals in learning English.

From the data presented above, it can be reported that the first semester English students of Faculty of Foreign Language in Mahasaraswati University motivation in learning English. Extrinsic motivation is a type of motivation which was derived from outside of the students. Harmer (2007) states that extrinsic motivation is the result of any number of outside factors, for example the need to pass an exam, the hope of financial reward or the possibility of future travel. There are some factors that influence the student extrinsic motivation such as students were motivated to learn English because they want to achieve their goals, for example: they want to get a good score in final exam, they want to get a good job during Covid-19 Pandemic and they may want to continue their study overseas. Furthermore, the students want English teacher have good method and personality in teaching and learning process during the Covid-19 Pandemic.

Then, from the calculation scores of students' intrinsic and extrinsic motivation above, it was found that the total mean score for intrinsic motivation is 4.20 and the total mean score for extrinsic motivation is 3.39. The researcher explained that the first semester English students of Faculty of Foreign Language in Mahasaraswati University have higher intrinsic motivation than extrinsic motivation in learning English during Covid-19 Pandemic. This is good for the student and teacher in teaching and laerning process. Because, motivation is the one of important thing which is affects students' attitude and achievement. In this finding, the students have good motivation, so it will be useful for the teacher to bring the student to be successful in learning English.

\section{CONCLUSION}

Having conducted the research, it can be reported that, there are two kinds of motivation found in this research such as: intrinsic motivation and extrinsic motivation. Based on the data presented in the research finding, it showed that the total mean score for students' intrinsic motivation is 4.20, it is considered as high rating level and the total mean score for students' extrinsic motivation is 3.39 , it is considered moderate in rating motivational level. From this result, it can be said 
that the students had intrinsic motivation higher than extrinsic motivation in learning English. In other words, the motivation inside of students were bigger than the motivation comes outside the students.

\section{REFERENCES}

Anugrah, R., \& Silitonga, J. (2020). Pendidikan Jarak Jauh / PJJ Saat Wabah Covid-19 Memengaruhi Motivasi Belajar Mahasiswa Akademi Keperawatan Hermina Manggala Husada. Jurnal Ilmiah Keperawatan Altruistik (JIKA), 3(2), 10-16.

Elliot, A. J., \& Murayama, K. (2008). On the Measurement of Achievement Goals: Critique, Illustration, and Application. Journal of Educational Psychology, 100(3), 613-628. https://doi.org/10.1037/00220663.100.3.613

Fuentes Hernández, S. S., Naren, A., \& Flórez, S. (2020). Online Teaching during Covid-19: How to Maintain Students Motivated in an EFL Class. Online) Journal Homepage, 6(2), 2409-109.

Hanafiah, N. (2010). Konsep Strategi Pembelajaran. Rafika Aditama.

Harmer, J. (2001). The Practice of English Language Teaching. Longman Pearson Education Limited.

Hawadi, A. R. dan. (2001). Psikologi Perkembangan Anak-Mengenal Bakat dan Kemampuan Anak. Grasindo.

Huang, Y. (2020). Research on Online Education in the Midst of the COVID-19 Pandemic. Journal of Advances in Education Research, 5(2), 125-137. https://doi.org/10.22606/jaer.2020.52005

Jefiza, A. (2017). Students' Motivation And Attitudes Toward Learning English in An English Course. Journal of Language Literature and Education, XII(12), 2-11.

Krishnapatria, K. (2020). From 'Lockdown' to Letdown: Students' Perception of E-learning amid the COVID-19 Outbreak. ELT in Focus, 3(1), 1-8. https://doi.org/10.35706/eltinfc.v3i1.3694

Lestari, Y. (2020). Pemanfaatan Jbclass Untuk Meningkatkan Motivasi Belajar Bahasa Inggris Peserta Didik Selama Masa Pandemi Covid-19 Using Jbclass To Enhance the Students 'Motivation in Learning English During Covid-19 Pandemic. 5(1), 114-122.

Morris, C.G. \& Maisto, A. A. (2002). Psychology:An introduction. Prentice Hall.

Pgri, U., Buana, A., \& Pertiwi, S. (2020). Learning Motivation and Students' Achievement in Learning English: A Case Study at Secondary School Students in the Covid-19 Pandemic Situation Agus Rahardjo. JELITA: Journal of English Language Teaching and Literature, 1(2), 2721-1916.

Purnama, N. A., Rahayu, N. S., \& Yugafiati, R. (2019). Students' Motivation in Learning English. PROJECT (Professional Journal of English Education), 2(4), 539. https://doi.org/10.22460/project.v2i4.p539-544

Purwanto, A., Fahlevi, M., Budi Santoso, P., Setyo Radyawanto, A., \& Anwar, C. (2020). Exploring the Covid-19 Pandemic Impact on the Indonesian Students Performance. Journal of Critical Review, 7(15), 2020-2035. 
Putri, I. G. A. V. W. (2019). Students' Influences of CAA: A Case Study of Senior High School in Badung Bali. International Journal for Educational and Vocational Studies, 1(1), 1. https://doi.org/10.29103/ijevs.v1i1.1392

Salamat, L., Ahmad, G., Bakht, M. I., \& Saifi, I. L. (2018). Effects of E-Learning on Students' Academic Learning at University Level. Assian Innovative Journal of Social Sciences \& Humanities (AIJSSH), 2 (2)(April), 1-12. https://doi.org/10.13140/RG.2.2.18234.49609

Sepora, T.M and Sepideh, M. J. (2012). Motivation, Its Types, and Its Impacts in Language Learning. International Journal of Business and Social Science, 3(34), 230-235. 